\title{
AKAD PEMBIAYAAN MURABAHAH BIL WAKALAH PADA PT. BANK RAKYAT INDONESIA SYARIAH LHOKSEUMAWE
}

\author{
AKAD FINANCING CHEAP BIL WAKALA ON \\ PT. BANK RAKYAT SYARIAH LHOKSEUMAWE
}

\author{
Zulfiyanda ${ }^{1}$, Faisal $^{2}$, Manfarisah ${ }^{3}$ \\ ${ }^{1}$ Hukum Perdata, Sekolah Tinggi Ilmu Hukum Albanna \\ Jln. Buloh, Duson Trieng Duaperade, Muara Dua, Lhokseumawe-Aceh \\ ${ }^{2}$ Hukum Ekonomi Islam, Fakultas Hukum, Universitas Malikussaleh \\ Jln. Jawa, Bukit Indah, Blang Pulo, Lhokseumawe-Aceh \\ ${ }^{3}$ Hukum Perdata, Fakultas Hukum, Universitas Malikussaleh \\ Jln. Jawa, Bukit Indah, Blang Pulo, Lhokseumawe-Aceh \\ Email: zulfiyanda.zy@gmail.com
}

\begin{abstract}
This research is based on the financing performed by Micro Sharia Unit at PT. Bank Rakyat Indonesia Syariah Lhokseumawe Branch in committing murabahah bil wakalah financing contract in advance of customer known as representative of Sharia Micro Unit at PT. Bank Rakyat Indonesia Syariah Lhokseumawe Branch purchases its goods. This study aims to analyze the implementation of murabahah bil wakalah financing scheme as well as the legal consequences of Sharia Micro Unit at PT. Bank Rakyat Indonesia Syariah Lhokseumawe Branch. This research uses qualitative method with empirical juridical approach method, that is the way to solve research problem by researching secondary data followed by doing research on primary data in the field.
\end{abstract}

Keywords: Financing, murabahah bil wakalah

\section{Intisari}

Penulisan ini dilatar belakangi pembiayaan yang dijalankan oleh Unit Mikro Syariah di PT. Bank Rakyat Indonesia Syariah Cabang Lhokseumawe dalam melakukan akad pembiayaan murabahah bil wakala, dimana nasabah sebagai wakil dari Unit Mikro Syariah untuk melakukan pembelian barang-barang kebutuhannya. Penelitian ini bertujuan untuk menganalisis pelaksanaan akad pembiayaan murabahah bil wakalah serta akibat hukumnya pada Unit Mikro Syariah di PT. Bank Rakyat Indonesia Syariah Cabang Lhokseumawe, selain itu juga untuk menganalisis hambatan dalam pelaksanaan akad pembiayaan murabahah bil wakalah serta upaya penyelesaiannya pada Unit Mikro Syariah di PT. Bank Rakyat Indonesia Syariah Cabang Lhokseumawe. Hasil penelitian, terdapat belum sesuai prosedur dalam pelaksanaan akad pembiayaan murabahah bil wakalah pada Unit Mikro Syariah di PT. Bank Rakyat Indonesia Syariah Cabang Lhokseumawe, sehingga dikhawatirkan tidak terpenuhinya prinsip syariah dan berakibat tidak sah dan batal demi hukum. Selain itu, terdapat 
hambatan yang mengakibatkan belum amanahnya Unit Mikro Syariah di PT. Bank Rakyat Indonesia Syariah Cabang Lhokseumawe menjalankan aktivitas pembiayaannya.

Kata Kunci: Pembiayaan, murabahah bil wakalah

\section{Pendahuluan}

Perkembangan industri perbankan syariah nasional sudah memiliki landasan hukum yang memadai, yaitu dengan telah diberlakukannya Undang-Undang Nomor 21 Tahun 2008 tentang Perbankan Syariah. Hal tersebut menguntungkan bagi sektor perekonomian perbankan syariah di Indonesia. Sebab, undang-undang tersebut telah memberikan angin segar bagi perbankan yang beroperasi dengan prinsip syariah untuk terus melaju dalam dunia perbankan di Indonesia.

Prinsip syariah adalah prinsip Hukum Islam dalam kegiatan perbankan berdasarkan fatwa yang dikeluarkan oleh lembaga yang memiliki kewenangan dalam penetapan fatwa di bidang syariah. ${ }^{1}$ Berdasarkan pengertian tersebut Lembaga yang memiliki kewenangan dalam penetapan fatwa di bidang syariah adalah fatwa yang dikeluarkan oleh Dewan Syariah Nasional-Majelis Ulama Indonesia (DSN-MUI), sebagaimana yang tertuang dalam Surat Keputusan Direksi Bank Indonesia Nomor 32/34/1999, dimana pada Pasal 31 dinyatakan: "Untuk melaksanakan kegiatankegiatan usahanya, bank umum syariah diwajibkan memperhatikan fatwa DSN-MUI". ${ }^{2}$

Selain yang telah diatur dalam Undang-Undang Nomor 21 Tahun 2008 Tentang Perbankan Syariah. Prinsip syariah dalam kegiatan perbankan juga telah dipertegas lagi dalam Peraturan Bank Indonesia Nomor 11/33/PBI/2009 tentang Pelaksanaan Good Corporate Governance Bagi Bank Umum Syariah dan Unit Usaha Syariah, dimana pada Pasal 1 Ayat 5 disebutkan bahwa: "Prinsip syariah adalah prinsip Hukum Islam di bidang perbankan syariah yang tertuang dalam bentuk fatwa Dewan SyariahNasional - Majelis Ulama Indonesia". ${ }^{3}$ Selain itu juga dalam Peraturan Otoritas Jasa Keuangan Nomor 24/POJK.03/2015 tentang Produk Dan Aktivitas Bank syariah Dan Unit Usaha Syariah, pada Pasal 18 Ayat 2 dijelaskan bahwa: ${ }^{4}$

Pemenuhan penerapan prinsip syariah sebagaimana dimaksud pada ayat (1), harus didukung dengan: (a) Fatwa Dewan Syariah Nasional Majelis Ulama Indonesia yang menjadi dasar penerbitan produk dan/atau pelaksanaan aktivitas; dan (b) Opini dari Dewan Pengawas Syariah bank terhadap produk dan/atau aktivitas.

\footnotetext{
${ }^{1}$ Indonesia, Undang-Undang Perbankan Syariah, UU Nomor 21 Tahun 2008, LN No. 94 Tahun 2008, Ps. 1 Ayat 12

${ }^{2}$ Aang Kunaifi, "Peran Dewan Syariah Nasional-Majelis Ulama Indonesia Dalam Perbankan Syariah",(Makalah Program Pasca Sarjana Universitas Sunan Giri Surabaya), Surabaya : 2013, Hlm 3

${ }^{3}$ Indonesia, Peraturan Bank Indonesia, PBI Nomor 11/33/PBI/2009, LN No. 175 Tahun 2009, Ps 1 Ayat 5

${ }^{4}$ Indonesia, Peraturan Otoritas Jasa Keuangan, POJK Nomor 24/POJK.03/2015, LN No. 289 Tahun 2015, Ps 18 Ayat 2
} 
Pasal-pasal di atas menjelaskan bahwa penerapan prinsip syariah dalam kegiatan ekonomi dan keuangan syariah khususnya perbankan syariah harus mengikuti fatwa yang dikeluarkan oleh DSN-MUI yang merupakan lembaga yang didirikan untuk memberikan ketentuanHukum Islam kepada lembaga keuangan syariah dalam menjalanan aktivitasnya. Ketentuan tersebut sangatlah penting dan menjadi dasar hukum utama dalam perjalanan operasinya. Tanpa adanya ketentuan hukum, termasukHukum Islam, maka lembaga keuangan syariah akan kesulitan dalam menjalankan aktivitasnya. ${ }^{5}$

Bank syariah merupakan lembaga intermediasi dan penyedia jasa keuangan yang bekerja berdasarkan etika dan sistem Islam, khususnya yang bebas dari bunga (riba), bebas dari kegiatan spekulatif dan perjudian (maysir), bebas dari hal-hal yang tidak jelas (gharar), berprinsip keadilan, dan hanya membiayai kegiatan usaha yang halal yang kesemuanya merupakan prinsip-prinsip perbankan syariah. Bank syariah sering dipersamakan dengan bank tanpa bunga. Bank tanpa bunga merupakan konsep yang lebih sempit dari bank syariah, dimana sejumlah instrumen atau operasinya bebas dari bunga. Bank syariah selain menghindari bunga, juga secara aktif ikut berpartisipasi dalam mencapai sasaran dan tujuan dari ekonomi Islam yang berorientasi pada kesejahteraan sosial. $^{6}$

PT. Bank Rakyat Indonesia Syariah Cabang Lhokseumawe resmi dibuka pada tanggal 03 Januari 2013, dengan telah di bukanya kantor cabang tersebut, PT. Bank Rakyat Indonesia Syariah Cabang Lhokseumawe telah menjadi mitra terbaru bagi masyarakat Kota Lhokseumawe. PT. Bank Rakyat Indonesia Syariah Cabang Lhokseumawe memberikan pelayanan kepada masyarakat dan memenuhi kebutuhan pasar di Kota Lhokseumawe, dari penghimpunan dana (funding), pembiayaan (landing) maupun produk-produk jasa (service) lainnya.

Pembiayaan merupakan salah satu produk utama yang dimiliki PT. Bank Rakyat Indonesia Syariah Cabang Lhokseumawe. Dengan pembiayaan yang fokus pada pengembangan segmen usaha menengah bawah, maka PT. Bank Rakyat Indonesia Syariah Cabang Lhokseumawe membuka Unit Mikro Syariah. Unit Mikro Syariah merupakan sebuah unit kerja yang memberikan pelayanan berupa pembiayaan kepada masyarakat yang memiliki usaha kecil dan menengah baik itu berupa dagang (trading), produksi (manufactur) dan jasa (service). Usaha yang dilakukan oleh Unit Mikro Syariah untuk merealisasikan tujuan dari masyarakat adalah dengan menerapkan prinsip murabahah dalam hal pembiayaan yang dapat dilakukan dengan menggunakan suatu akad pembiayaan.

Murabahah adalah transaksi jual beli, yaitu pihak bank syariah bertindak sebagai penjual dan nasabah sebagai pembeli, dengan harga jual dari bank adalah harga

\footnotetext{
${ }^{5}$ Sartono Kartodirodjo dalam Cholil Nafis, Teori Hukum Ekonomi Syariah, (Jakarta: UI-Press, 2011), hlm 90

${ }^{6}$ Muhammad Fauzi, Analisis Faktor-Faktor Yang Mempengaruhi Keinginan Migrasi Nasabah Bank Umum Syariah di Kota Semarang, (Semarang: IAIN Walisongo, 2008), hlm 11.
} 
beli dari pemasok ditambah keuntungan dalam persentase tertentu bagi bank syariah sesuai dengan kesepakatan. Kepemilikan barang akan berpindah kepada nasabah segera setelah perjanjian jual beli ditandatangani dan nasabah akan membayar barang tersebut dengan cicilan tetap yang besarnya sesuai kesepakatan sampai dengan pelunasannya. ${ }^{7}$ Murabahah di dalam Al-Qur'an tidak ada secara langsung dibahas, tetapi disana terdapat sejumlah acuan transaksi perdagangan seperti jual beli, laba dan rugi. Begitupun di dalam Hadits Nabi Muhammad Saw tidak terdapat pembahasan langsung mengenai murabahah. Para ulama generasi awal seperti Malik dan Syafi'i yang secara khusus mengatakan bahwa jual beli murabahah halal, tidak memperkuat pendapat mereka dengan satu Hadits pun. ${ }^{8}$ Di dalam Islam, murabahah merupakan salah satu bentuk jual beli yang bersifat amanah. Jual beli bersifat amanah dapat diartikan sebagai jual beli transparan, yaitu penjual mempunyai keharusan untuk memberitahukan harga pokok dan keuntungan yang diambil dari barang yang dijual tersebut kepada pembeli secara jujur. Ketidakjujuran dalam melakukan transaksi jual beli yang bersifat amanah termasuk di dalamnya melakukan tindakan berupa diam semata maka dapat diartikan sebagai salah satu penipuan. ${ }^{9}$

Pengertian murabahah di atas memberikan penjelasan bahwa fungsi bank syariah adalah sebagai penjual barang untuk kepentingan nasabah, dengan cara membeli barang yang diperlukan nasabah dan kemudian menjualnya kembali kepada nasabah dengan harga jual yang setara dengan harga beli ditambah keuntungan bank. Bank harus memberitahukan secara jujur harga pokok barang berikut biaya yang diperluan dan menyampaikan semua hal yang berkaitan dengan pembelian barang kepada nasabah.

Pada pelaksanaannya, bank syariah tidak bersedia melakukan pembelian barang atau menyediakannya. Karenanya bank syariah menggunakan media akad wakalah. Akad Wakalah merupakan suatu akad pelimpahan kekuasaan oleh satu pihak (muwakkil) kepada pihak lain (wakil) dalam hal-hal yang boleh diwakilkan atau perwakilan antara kedua belah pihak (bank dan nasabah) dimana bank memberikan kuasa kepada nasabah untuk mewakili dalam melakukan pekerjaan atau jasa tertentu.

Unit Mikro Syariah di PT. Bank Rakyat Indonesia Syariah Cabang Lhokseumawe dalam pelaksanaan pembiayaannya menyerahkan berupa uang kepada nasabah dan bukan berupa barang sesuai dengan kebutuhan nasabah. Hal itu dikarenakan Unit Mikro Syariah di PT. Bank Rakyat Indonesia Syariah Cabang Lhokseumawe selain menggunakan akad murabahah juga menggunakan akad wakalah, atau yang disebut dengan akad pembiayaan murabahah bil wakalah.

${ }^{7}$ Zainuddin Ali, Hukum Perbankan Syariah,( Jakarta : Sinar Grafika, 2007), hlm 30

${ }^{8}$ Muhammad, Manajemen Pembiayaan Bank Syariah, (Yogyakarta: AMP YKPN, 2005), hlm 119

${ }^{9}$ Faisal, Metode Anuitas Dan Proporsional Murabahah Sebagai Bentuk Transparansi Dan Publikasi Laporan Bank, Mimbar Hukum Volume 26, Nomor 3, Oktober 2014. Dikutip Dari Syamsul Anwar, Studi Hukum Islam Kontemporer, (Jakarta: RM Books, 2007), hlm 168. 
Unit Mikro Syariah di PT. Bank Rakyat Indonesia Syariah Cabang Lhokseumawe melakukan akad pembiayaan murabahah bil wakalah sebelum nasabah sebagai wakil dari Unit Mikro Syariah melakukan pembelian barang-barang kebutuhannya. Setelah pembelian tersebut, secara langsung nasabah memiliki barangbarang tersebut dan hanya menyerahkan bukti pembelian berupa kwitansi atau faktur kepada Unit Mikro Syariah, sehingga Unit Mikro Syariah tidak memiliki lebih dulu barang-barang yang telah dibeli oleh nasabah tersebut. Berdasarkan uraian di atas, penulis tertarik untuk melakukan suatu kajian yang membahas bagaimana pelaksanaan akad pembiayaan murabahah bil wakalah serta akibat hukumnya pada Unit Mikro Syariah di PT. Bank Rakyat Indonesia Syariah Cabang Lhokseumawe.

\section{Pembahasan}

PT. Bank Rakyat Indonesia Syariah Cabang Lhokseumawe resmi memulai kegiatan operasionalnya pada tanggal 03 Januari 2013 yang ditandai dengan peresmian Kantor Cabang Lhokseumawe yang berlamat Jl. B. Aceh-Medan, Gampong Meunasah Mesjid, Kec. Muara Dua, Kota Lhokseumawe. Dengan telah diresmikannya kantor tersebut, PT. Bank Rakyat Indonesia Syariah Cabang Lhokseumawe sudah dapat memberikan pelayanan kepada masyarakat baik itu penghimpunan dana (funding), pembiayaan (landing) dan produk-produk jasa (service) lainnya.

PT. Bank Rakyat Indonesia Syariah Cabang Lhokseumawe di dalam menjalankan aktivitas bisnisnya terutama dalam pembiayaan memiliki sebuah unit kerja yang diberi nama dengan Unit Mikro Syariah. Adapun unit tersebut diisi oleh beberapa karyawan yang memiliki tugas sebagai berikut:

1. Micro Marketing Manager (MMM), secara struktur berada langsung di bawah Pimpinan Cabang, yang membawahi Collection Supervisor dalam 1 area cabang, tidak secara langsung membawahi Unit Head (UH) tetapi tetap melakukan koordinasi dan control terhadap pencapaian hasil target dari Unit Head (UH) yang masih berada di areanya dan mempunyai kewajiban untuk selalu berkoordinasi dengan Bussiness and Distribution Departement di Micro Business Group kantor pusat untuk pencapaian target sales dan segala hal yang berhubungan dengan bisnis mikro yang berada di areanya.

2. Unit Head (UH), secara struktur berada langsung di bawah Pimpinan Cabang Pembantu (Pincapem) sehingga pencapaian target dari Unit Head (UH) juga menjadi tanggung jawab dari Pimpinan Cabang Pembantu (Pincapem). Unit Head (UH) bertanggung jawab untuk melaksanakan dan memastikan bisnis mikro pada unit tersebut berjalan sesuai target yang diberikan dan tidak melanggar Syariah comply maupun P3 mikro. Unit Head (UH) membawahi beberapa Accout Officer Micro (AOM).

3. Account Officer Micro (AOM), secara struktur berada langsung di bawah Unit Head (UH) dan bertugas untuk melakukan penjualan produk-produk mikro serta melakukan pre-screening untuk calon-calon nasabah sebelum dokumen-dokumen pembiayaan diberikan kepada Unit Head (UH) untuk diverifikasi lebih lanjut. 
Unit Mikro Syariah sebagai salah satu segmen bisnis syariah yang ada di PT. Bank Rakyat Indonesia Syariah Cabang Lhokseumawe memiliki pilihan variasi yang dapat membantu nasabah untuk memenuhi kebutuhannya, sehingga Unit Mikro Syariah dapat menyelesaikan masalah-masalah dalam hal permodalan dan dapat menjadi bank syariah pilihan calon nasabah dalam upaya mengembangkan usahanya.

Besarnya jumlah pembiayaan berawal dari pengajuan calon nasabah yang selanjutnya akan ditentukan oleh petugas Unit Mikro Syariah dengan melakukan analisa kelayakan pembiayaan terhadap calon nasabah yang terdiri dari:

1. Karakter (Character);

2. Kemampuan atau kapasitas nasabah (Capacity);

3. Jaminan/agunan (Collateral);

4. Permodalan atau asset usaha (Capital);

5. Kondisi ekonomi dari usaha nasabah (Condition Of Economi).

Adapun persyaratan dokumen yang harus dilengkapi oleh calon nasabah pembiayaan Unit Mikro Syariah:

1. Surat keterangan Usaha (SKU) dari dinas terkait, seperti dari kelurahan/ kecamatan atau dinas pasar atau juga dinas terkait lainnya;

2. Copy identitas nasabah dan pasangan;

3. Copy Kartu Keluarga (KK) dan Akta Nikah atau surat keterangan belum menikah dari kelurahan atau surat keterangan meninggal dunia (jika pasangan telah meninggal);

4. Copy NPWP untuk pembiayaan > Rp. 50.000.000,-

5. Copy bukti dokumen agunan.

Untuk merealisasikan produk-produk pembiayaan Unit Mikro Syariah yang menjadi tujuan dari nasabah yang mengajukan pembiayaan, maka digunakan suatu akad yaitu akad murabahah bil wakalah. Murabahah pada awalnya merupakan konsep jual beli yang sama sekali tidak ada hubungannya dengan pembiayaan. Akan tetapi bentuk jual beli ini kemudian dipergunakan oleh perbankan syariah dengan memadukan beberapa konsep lain menjadi suatu bentuk pembiayaan.

Pembiayaan yang terjadi pada Unit Mikro Syariah di PT. Bank Rakyat Indonesia Syariah Cabang Lhokseumawe belum dapat berjalan secara ideal. Karena hal tersebut disebabkan bank belum bisa menjalankan konsep murabahah dalam perdagangan pada umumnya yaitu bank seharusnya menyediakan barang-barang yang dibutuhkan oleh nasabah dalam bentuk stock. Akan tetapi apabila bank melakukan hal tersebut, bank akan menanggung kerugian akibat adanya barang yang tidak terjual, sehingga untuk mengatasinya bank mewakilkan dengan menggunakan akad wakalah kepada nasabah untuk membeli barang-barang yang dibutuhkan nasabah.

Nasabah yang menjadi wakil dari bank melakukan pembelian sesuai kebutuhannya secara langsung, dengan kata lain bank memberikan kuasa kepada nasabah dan bank tidak harus berhubungan dengan suplier (baik grosir maupun distributor). Setelah pembelian tersebut nasabah menyerahkan kwitansi atau faktur kepada bank sebagai bukti dari pembelian. 
Pada pelaksanaan akad pembiayaan di Unit Mikro Syariah PT. Bank Rakyat Indonesia Syariah Cabang Lhokseumawe, ketika permohonan pembiayaan nasabah telah disetujui, maka selanjutnya akan dilakukan proses akad. Dalam proses akad tersebut nasabah dan pihak bank menanda tangani akad murabahah dan akad wakalah pada waktu yang sama. Setelah proses akad selesai, selanjutnya nasabah sebagai wakil dari bank menerima uang dari pembiayaan tersebut untuk membeli barang-barang sesuai dengan kebutuhannya yang nantinya nasabah harus menyerahkan kwitansi atau faktur pembelian kepada bank. Dengan demikian, dalam pengembaliannya nasabah dapat melakukannya secara angsuran sesuai jangka waktu yang telah disepakati. ${ }^{10}$

Mekanisme pelaksanaan akad pembiayaan murabahah bil wakalah yang dijalankan Unit Mikro Syariah adalah sebagai berikut: ${ }^{11}$

1. Calon nasabah membutuhkan tambahan modal usaha namun belum mempunyai cukup dana tunai, kemudian mengajukan pembiayaan murabahah bil wakalah pada bank syariah, setelah memenuhi syarat-syarat pengajuan permohonan, terjadi negosiasi margin antara nasabah dengan bank syariah;

2. Setelah proses negosiasi, dilanjutkan analisa usaha dan jaminan yang kemudian menghasilkan persetujuan atau tidaknya pembiayaan;

3. Setelah disetujui pembiayaan dan terjadi kesepakatan bersama maka terjadi akad murabahah bil wakalah;

4. Setelah terjadi akad murabahah bil wakalah, maka bank syariah menyerahkan dana kepada nasabah sebagai wakil dari bank untuk membeli barang sesuai yang diinginkan oleh nasabah sebagaimana yang telah menjadi kesepakatan dalam akad murabahah bil wakalah;

5. Pihak nasabah telah menerima barang dari supplier dan menyerahkan kwitansi atau faktur pembelian dan foto-foto barang yang telah dibeli kepada bank syariah;

6. Nasabah akan membayar/mengembalikan dana berupa harga pokok ditambah dengan margin keuntungan yang telah disepakati secara angsuran atau secara sekaligus/pelunasan dipercepat.

Menurut hasil wawancara dengan Herman yang merupakan salah satu nasabah pembiayaan Unit Mikro Syariah yang memiliki usaha dagang di Pasar Inpres Kota Lhokseumawe. Setelah permohonan pembiayaannya disetujui, nasabah melakukan kesepakatan dengan Unit Mikro Syariah dengan menanda tangani akad murabahah dan akad wakalah pada waktu yang sama. Setelah itu nasabah menerima uang pembiayaan tersebut untuk dibelanjakan sesuai kebutuhan nasabah, yang selanjutnya nasabah harus menyerahkan kwintasi pembelian barang tersebut kepada Unit Mikro Syariah. ${ }^{12}$

Selain itu, menurut salah satu nasabah yang bernama Darmawi, yang memiliki usaha dagang yang beralamat di Desa Aluelim Kota Lhokseumawe, bahwasanya

\footnotetext{
${ }^{10}$ Wawancara dengan Syamsul Bahri, Account Officer Mikro (AOM) Unit Mikro Syariah di PT. Bank Rakyat Indonesia Syariah Cabang Lhokseumawe di Lhokseumawe Tanggal 02 Februari 2018

${ }^{11}$ Wawancara dengan Zamil, Account Officer Mikro (AOM) Unit Mikro Syariah di PT. Bank Rakyat Indonesia Syariah Cabang Lhokseumawe di Lhokseumawe Tanggal 02 Februari 2018

12 Wawancara dengan Herman, Nasabah Unit Mikro Syariah PT. Bank Rakyat Indonesia Syariah Cabang Lhokseumawe, Tanggal 03 Februari 2018
} 
pembiayaan yang nasabah terima dari bank syariah sama dengan bank konvensional, karena nasabah melihat di dalam pembiayaan ini tidak ada pengalihan barang dari bank ke nasabah walaupun secara prinsip atau adanya serah terima. Selain itu, akad murabahah bil wakalah ditanda tangani nasabah sebelum nasabah menerima dana, dan nasabah hanya menyerahkan kwitansi setelah nasabah membeli segala kebutuhannya. 13

Apabila melihat penjelasan dari beberapa narasumber di atas, maka dapat digambarkan pelaksanaan akad pembiayaan murabahah bil wakalah yang dijalankan oleh Unit Mikro Syariah di PT. Bank Rakyat Indonesia Syariah Cabang Lhokseumawe sebagai berikut:

Skema 1: Berdasarkan pelaksanaan dilapangan

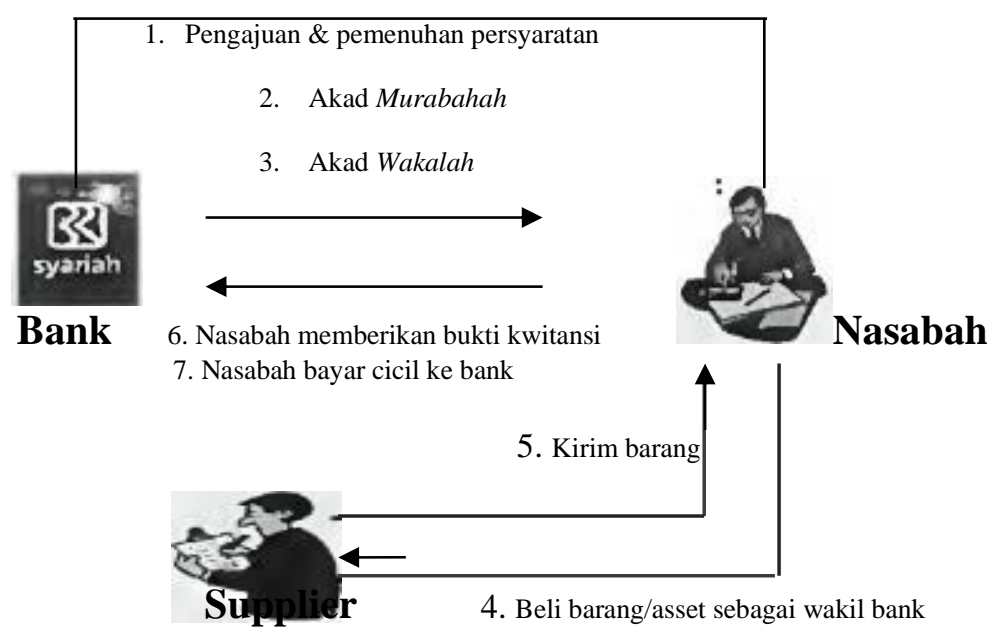

Skema di atas ini dibuat berdasarkan pelaksanaan akad pembiayaan murabahah bil wakalah di Unit Mikro Syariah PT. Bank Rakyat Indonesia Syariah Cabang Lhokseumawe, terjadinya pemberian dana kepada nasabah sebagai wakil dari bank untuk membeli sendiri kebutuhannya, dilakukan setelah akad murabahah yang diikuti dengan akad wakalah ditanda tangani.

Dengan demikian, Unit Mikro Syariah di PT. Bank Rakyat Indonesia Syariah Cabang Lhokseumawe tidak berfungsi sebagai penjual barang seperti pada industri perdagangan yang menjual secara langsung kepada pembeli. Peran Unit Mikro Syariah di PT. Bank Rakyat Indonesia Syariah Cabang Lhokseumawe dalam pembiayaan murabahah bil wakalah lebih tepat digambarkan sebagai pemberi pinjaman bukan pemberi pembiayaan.

Namun, berdasarkan wawancara dengan Branch Operasional Supervisor (BOS) di PT. Bank Rakyat Indonesia Syariah Cabang Lhokseumawe yang bernama Maulizar, dalam pembiayaan Unit Mikro Syariah di PT. Bank Rakyat Indonesia Syariah Cabang

\footnotetext{
${ }^{13}$ Wawancara dengan Darmawi, Nasabah Unit Mikro Syariah PT. Bank Rakyat Indonesia Syariah Cabang Lhokseumawe, Tanggal 10 Februari 2018
} 
Lhokseumawe, sebelum dilakukan proses pencairan dana kepada nasabah, dokumendokumen pembiayaan nasabah harus diserahkan dahulu kepada Branch Operasional Supervisor (BOS) untuk diperiksa kelengkapannya, baik itu dokumen identitas nasabah, form kelengkapan pembiayaan, form peretujuan pembiayaan maupun dokumen pengikatan dan jaminan yang diperiksa melalui cheklist dokumen pembiayaan mikro. Akan tetapi, dalam pemeriksaan dokumen yang dilakukan oleh Branch Operasional Supervisor (BOS) melalui cheklist dokumen pembiayaan mikro tidak ada syarat untuk melampirkan akad murabahah bil wakalah dalam proses pencairan dana kepada nasabah, sehingga akad murabahah bil wakalah tidak menjadi syarat yang harus dipenuhi dalam proses pencairan dana kepada nasabah. Namun dalam pelaksanaan pembiayaan yang dijalankan oleh Unit Mikro Syariah di PT. Bank Rakyat Indonesia Syariah Cabang Lhokseumawe, akad murabahah bil wakalah ditandatangani sebelum proses pencairan dana kepada nasabah. ${ }^{14}$

Dengan demikian, apabila melihat dari operasional system PT. Bank Rakyat Indonesia Syariah Cabang Lhokseumawe, seharusnya Unit Mikro Syariah di PT. Bank Rakyat Indonesia Syariah Cabang Lhokseumawe tidak melakukan akad murabahah bil wakalah sebelum proses pencairan dana kepada nasabah, akan tetapi akad murabahah bil wakalah tersebut dilakukan setelah nasabah menerima dana dan membeli barangbarang kebutuhannya, karena akad murabahah bil wakalah tidak menjadi syarat dalam bagian operasional melakukan pencairan dana pembiayaan kepada nasabah.

Sebagaimana dari penelitian di atas, pelaksanaan akad pembiayaan murabahah bil wakalah pada Unit Mikro Syariah di PT. Bank Rakyat Indonesia Syariah Cabang Lhokseumawe, dihubungkan menurut peraturan internal di PT. Bank Rakyat Indonesia Syariah, dalam Surat Keputusan Nomor 028-MDO/03-2015 tentang Pedoman Pemberian Pembiayaan (P3) Mikro PT. Bank Rakyat Indonesia Syariah, dalam BAB II Produk Pembiayaan Mikro, bagian Skema Pembiayaan Murabahah dengan Wakalah:

${ }^{14}$ Wawancara dengan Maulizar, Branch Operasional Supervisor (BOS) PT. Bank Rakyat Indonesia Syariah Cabang Lhokseumawe di Lhokseumawe Tanggal 03 Februari 2018 
Skema 2: Berdasarkan Surat Keputusan Nomor 028-MDO/03-2015 tentang Pedoman Pemberian Pembiayaan (P3) Mikro PT. Bank Rakyat Indonesia Syariah

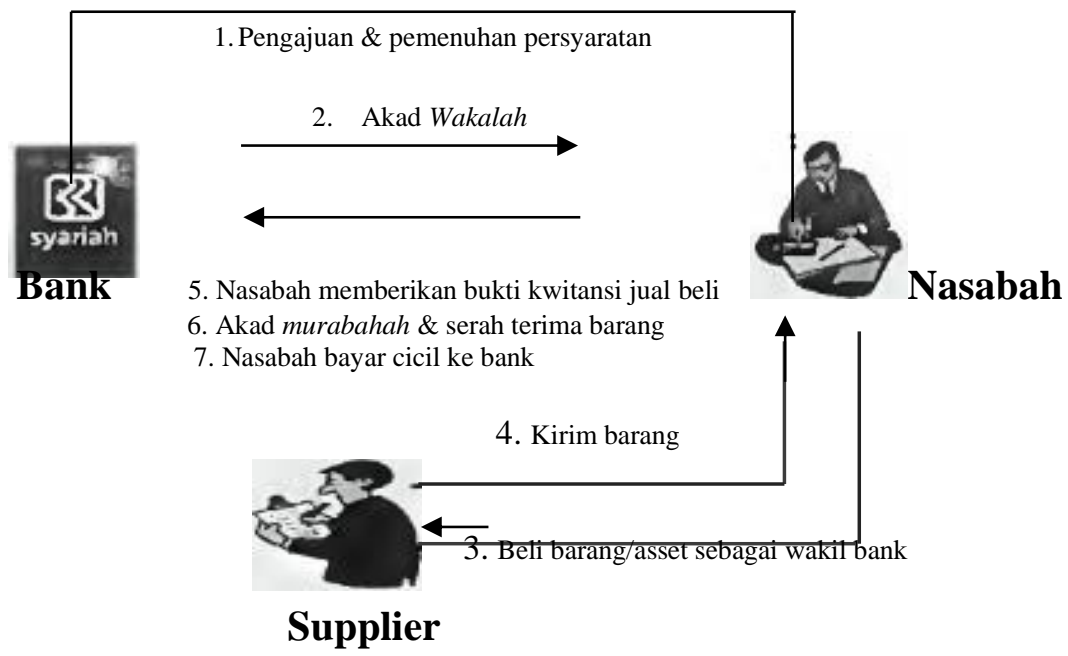

Skema pembiayaan Murabahah dengan wakalah ini digunakan pada saat bank tidak dapat secara langsung melakukan pembelian terhadap barang-barang yang dibutuhkan oleh nasabah.

Penjelasan Skema:

1. Nasabah mengajukan pembiayaan untuk tambahan modal atau investasi dan melengkapi dokumen pembiayaan yang dibutuhkan untuk proses pembiayaan;

2. Atas asset sebagai obyek murabahah, jika bank tidak dapat melakukan pembelian secara langsung kepada Supplier, maka dilakukan akad wakalah kepada nasabah;

3. Nasabah sebagai wakil bank membeli yang dibutuhkan sebagai modal atau investasi kepada Supplier sesuai tujuan pembiayaan;

4. Supplier mengirimkan / menyerahkan asset;

5. Atas asset yang telah dibeli oleh nasabah sebagai wakil bank maka nasabah memberikan bukti kwitansi jual beli dari Supplier kepada bank;

6. Antara bank dan nasabah melakukan akad murabahah yang disertai serah terima obyek murabahah;

7. Pembayaran asset dapat dilakukan secara bulanan.

Skema berdasarkan Surat Keputusan Nomor 028-MDO/03-2015 tentang Pedoman Pemberian Pembiayaan (P3) Mikro PT. Bank Rakyat Indonesia Syariah di atas, dapat dijelaskan bahwasanya akad murabahah dilakukan setelah asset dibeli oleh nasabah dan setelah itu nasabah menyerahkan bukti kwitansi jual beli dari supplier kepada bank. Selain itu jika melihat dari skema tersebut jelas bahwa akad wakalah dilakukan pada proses awal pengikatan pembiayaan nasabah, sehingga akad pembiayaan murabahah bil wakalah seharusnya dilakukan tidak pada waktu bersamaan, tetapi harus ada jeda waktu sampai asset yang menjadi obyek murabahah terpenuhi yang setelah itu dilanjutkan dengan serah terima melalui akad murabahah. 
Dengan demikian, terjadi suatu pelanggaran dari pelaksanaan akad pembiayaan murabahah bil wakalah yang dijalankan oleh Unit Mikro Syariah di PT. Bank Rakyat Indonesia Syariah Cabang Lhokseumawe, yaitu dalam pelaksanaannya tidak sesuai dengan Surat Keputusan Nomor 028-MDO/03-2015 tentang Pedoman Pemberian Pembiayaan (P3) Mikro PT. Bank Rakyat Indonesia Syariah. Namun, pada pelaksanaannya pelanggaran tersebut tidak menjadi suatu temuan audit di PT. Bank Rakyat Indonesia Syariah, baik itu dari internal audit cabang maupun internal audit pusat atau yang biasa disebut dengan Satuan Kerja Audit Internal (SKAI).

Bank Indonesia yang memiliki fungsi sebagai central bank juga mengatur kegiatan bank syariah dalam pemberian pembiayaan khususnya pembiayaan murabahah, yang dituangkan dalam Peraturan Bank Indonesia (PBI) No. 7/46/PBI/2005 tentang Akad Penghimpunan dan Penyaluran Dana Bagi Bank Yang Melaksanakan Kegiatan Usaha Berdasarkan Prinsip Syariah, dalam Pasal 9 Angka (1) Huruf (d) disebutkan: "Dalam hal bank mewakilkan kepada nasabah (wakalah) untuk membeli barang, maka akad murabahah harus dilakukan setelah barang secara prinsip menjadi milik bank".

Penjelasan Pasal 9 Angka (1) Huruf (d) dari Peraturan Bank Indonesia di atas, yang dimaksud dengan secara prinsip barang milik bank dalam wakalah pada akad murabahah adalah adanya aliran dana yang ditujukan kepada pemasok barang atau dibuktikan dengan kwitansi pembelian. Bank harus mencairkan dana kepada nasabah untuk membeli barang yang diperlukan nasabah sebelum akad murabahah ditandatangani. Hal ini akan dibuktikan melalui adanya aliran dana yang ditujukan kepada pemasok barang atau dibuktikan dengan kwitansi pembelian.

Dengan demikian, pelaksanaan pembiayaan yang dilakukan oleh Unit Mikro Syariah di PT. Bank Rakyat Indonesia Syariah Cabang Lhokseumawe, bertentangan dengan penjelasan Pasal 9 angka (1) huruf (d) Peraturan Bank Indonesia (PBI) No. 7/46/PBI/2005 tentang Akad Penghimpunan dan Penyaluran Dana Bagi Bank Yang Melaksanakan Kegiatan Usaha Berdasarkan Prinsip Syariah, dimana dalam aturan tersebut harus didahulukan akad wakalah, dan akad murabahah dapat dilakukan setelah nasabah menyerahkan bukti pembelian kepada bank syariah. Akan tetapi, dalam pelaksanaanya Unit Mikro Syariah di PT. Bank Rakyat Indonesia Syariah Cabang Lhokseumawe melakukan akad murabahah sebelum barang secara prinsip menjadi milik bank, seperti yang telah dijelaskan sebelumnya dalam skema 1 di atas. Dengan demikian, pelaksanaan akad pembiayaan murabahah bil wakalah yang dilakukan oleh Unit Mikro Syariah di PT Bank Rakyat Indonesia Syariah Cabang Lhokseumawe tidak sesuai dengan hukum sebagaimana yang dijelaskan dalam Peraturan Bank Indonesia (PBI) No. 7/46/PBI/2005 tentang Akad Penghimpunan dan Penyaluran Dana Bagi Bank Yang Melaksanakan Kegiatan Usaha Berdasarkan Prinsip Syariah.

Menurut fatwa DSN No. 04/DSN-MUI/IV/2000 tentang Murabahah, pada Bagian Pertama: Ketentuan umum murabahah dalam bank syariah, Angka 9 disebutkan: "Jika bank hendak mewakilkan kepada nasabah untuk membeli barang dari pihak ketiga, akad jual beli murabahah harus dilakukan setelah barang, secara prinsip, 
menjadi milik bank". Berdasarkan fatwa DSN tersebut, pemberian kuasa (wakalah) dari bank kepada nasabah dilakukan sebelum akad jual beli murabahah ditanda tangani, dan akad jual beli murabahah dilakukan setelah nasabah sebagai penerima kuasa membeli barang-barang sesuai dengan kebutuhannya.

Pelaksanaan akad pembiayaan murabahah bil wakalah yang dilakukan oleh Unit Mikro Syariah di PT. Bank Rakyat Indonesia Syariah Cabang Lhokseumawe, ditemukan adanya ketentuan umum yang tidak terpenuhi dalam pelaksanaan pembiayaan berdasarkan prinsip syariah. Ketentuan yang tidak terpenuhi tersebut yaitu mengadakan akad murabahah sebelum barang dibeli oleh nasabah sebagai wakil dan barang secara prinsip belum menjadi milik bank, sehingga pelaksanaan akad pembiayaan murabahah bil wakalah yang dilaksanakan oleh Unit Mikro Syariah di PT. Bank Rakyat Indonesia Syariah Cabang Lhokseumawe termasuk kategori pinjaman biasa (kredit) dengan tambahan keuntungan dan hal ini termasuk riba dan juga mengandung unsur gharar (hal-hal yang tidak jelas dan meragukan).

Riba yang terjadi pada Unit Mikro Syariah di PT. Bank Rakyat Indonesia Syariah Cabang Lhokseumawe adalah terjadinya kesalahan prosedur pembiayaan yang dilakukan oleh Unit Mikro Syariah di PT. Bank Rakyat Indonesia Syariah Cabang Lhokseumawe yang berakibat tidak terpenuhinya prinsip jual beli murabahah, sehingga pembiayaan tersebut menyerupai kredit yang mengandung unsur bunga. Riba adalah pengambilan tambahan dari modal pokok secara bathil. Dikatakan bathil karena pemilik modal mewajibkan peminjam untuk membayar lebih dari yang dipinjam tanpa memperhatikan apakah peminjam mendapat keuntungan atau mengalami kerugian. Riba dilarang dalam ajaran Islam, sebagaimana disebutkan dalam QS. Al-Baqarah Ayat 275 yang artinya: "Padahal Allah telah menghalalkan jual beli dan mengaramkan riba". Ayat tersebut menjelaskan bahwa Allah mengutuk keras mereka yang mengambil riba, menegaskan perbedaan yang jelas antara perniagaan dan riba.

Gharar yang terjadi pada Unit Mikro Syariah di PT. Bank Rakyat Indonesia Syariah Cabang Lhokseumawe adalah dilakukan murabahah sedangkan barang belum ada. Padahal dalam rukun murabahah harus ada mabi' (barang). Di saat cacat rukun murabahah maka dapat dikatakan bahwa murabahah itu tidak sah. Mabi' merupakan objek yang harus terta 'yin dalam akad jual beli, disaat mabi' tidak jelas unsur gharar sangat besar terjadi. Dalam ajaran Islam sangat apresiatif agar tidak terjadi gharar, hal tersebut seperti yang disebutkan dalam QS. An-Nisa Ayat 29 yang artinya: "Hai orangorang yang beriman, janganlah kamu saling memakan harta sesamamu dengan jalan yang bathil, kecuali dengan jalan perniagaan yang berlaku dengan suka sama suka di antara kamu".

Hubungan antara Unit Mikro Syariah di PT. Bank Rakyat Indonesia Syariah Cabang Lhokseumawe dengan nasabahnya adalah suatu hubungan hukum. Sebagai suatu hubungan hukum, maka dari hubungan-hubungan hukum inilah terbit suatu hak dan kewajiban bagi para pihak. Dalam hubungan hukum ditentukan sejumlah aturan yang disepakati bersama oleh para pihak yang bersangkutan, seperti pemenuhan hak disatu sisi dan pemenuhan hak disisi lainnya. Tidak dipenuhinya hak satu pihak akan berakibat bagi pihak lainnya, seperti tuntutan hukum dan tuntutan hukum inilah yang 
menjadi akibat hukum oleh karena tidak dipenuhinya suatu hak tertentu oleh pihak tertentu tersebut. Diantara Unit Mikro Syariah di PT. Bank Rakyat Indonesia Syariah Cabang Lhokseumawe dengan nasabahnya terdapat hubungan hukum yang terwujud dalam suatu akad pembiayaan. Dalam hubungan hukum itulah terdapat akibat hukum tertentu seperti tidak terpenuhinya prinsip syariah dalam akad pembiayaan murabahah bil wakalah, sehingga menimbulkan suatu akibat hukum antara bank dengan nasabah.

Akibat hukum merupakan suatu tindakan yang dilakukan untuk memperoleh suatu akibat yang dikehendaki oleh pelaku dan yang diatur oleh hukum. Tindakan yang dilakukannya merupakan tindakan hukum yakni tindakan yang dilakukan guna memperoleh sesuatu akibat yang dikehendaki hukum.

Pelaksanaan akad pembiayaan murabahah bil wakalah yang dilakukan oleh Unit Mikro Syariah di PT. Bank Rakyat Indonesia Syariah Cabang Lhokseumawe seperti yang telah dijelaskan sebelumnya bahwa terjadi suatu kesalahan dalam prosedur jual beli murabahah dengan menggunakan wakalah, sehingga tidak terpenuhinya prinsip syariah. Oleh sebab itu, pelaksanaan pembiayaan tersebut timbul suatu akibat hukum, yaitu akibat tidak sah dan batal demi hukum.

Unit Mikro Syariah di PT. Bank Rakyat Indonesia Syariah Cabang Lhokseumawe yang merupakan bagian dari perbankan syariah di Indonesia, sahnya suatu akad pembiayaan harus memenuhi rukun dan syarat serta prinsip syariah, sebagaimana yang diatur dalam Pasal 19 Ayat 1 Huruf d Undang-Undang Nomor 21 Tahun 2008 tentang Perbankan Syariah yang menjelaskan sebagai berikut: "Menyalurkan pembiayaan berdasarkan akad murabahah, akad salam, akad istishna atau akad lain yang tidak bertentangan dengan prinsip Syariah". Dengan demikian, prinsip syariah wajib untuk diterapkan di dalam bank syariah menjalankan aktivitas pembiayaannya.

Secara umum dalam Islam, salah satu syarat sahnya suatu akad adalah tidak menyalahi hukum syariah yang disepakati, artinya adanya suatu akad yang dilakukan oleh para pihak itu bukanlah perbuatan yang bertentangan dengan hukum atau perbuatan yang melawan hukum syariah. Sebab akad yang bertentangan dengan ketentuan hukum syariah adalah tidak sah, dan dengan sendirinya tidak ada kewajiban bagi masing-masing pihak untuk menempati atau melaksanakan akad tersebut. Kebatalan suatu akad yang melawan hukum merujuk kepada hadits Rasulullah SAW yang artinya sebagai berikut, "Segala bentuk persyaratan yang tidak ada dalam kitab Allah adalah bathil, sekalipun seribu syarat". Dengan kata lain apabila Unit Mikro Syariah di PT. Bank Rakyat Indonesia Syariah Cabang Lhokseumawe dalam melaksanakan akad pembiayaan murabahah bil wakalah tidak terpenuhinya prinsip syariah, maka akad pembiayaan yang diadakan dengan sendirinya batal demi hukum, sehingga akad pembiayaan murabahah bil wakalah pada Unit Mikro Syariah di PT. Bank Rakyat Indonesia Syariah Cabang Lhokseumawe dianggap tidak pernah ada atau tidak pernah terjadi suatu perikatan, dan tidak ada kewajiban bagi nasabah dan bank syariah untuk melaksanakan akad pembiayaan tersebut.

Kesalahan prosedur dalam pelaksanaan akad pembiayaan murabahah bil wakalah pada Unit Mikro Syariah di PT. Bank Rakyat Indonesia Syariah Cabang 
Lhokseumawe yang berakibat tidak sah dan batal demi hukum, tentunya menimbulkan suatu akibat hukum yang harus dipertanggung jawabkan kepada Bank Indonesia sebagai central bank dan Otoritas Jasa Keuangan yang memiliki kewenangan untuk melakukan pengaturan, pengawasan, pemeriksaan dan penyidikan seluruh aktivitas perbankan syariah di Indonesia.

Menurut Undang-Undang Nomor 21 Tahun 2008 tentang Perbankan Syariah, Pasal 56 dijelaskan:

Bank Indonesia menetapkan sanksi administratif kepada bank syariah atau UUS, anggota dewan komisaris, anggota Dewan Pengawas Syariah, direksi, dan/atau pegawai bank syariah atau bank umum konvensional yang memiliki UUS, yang menghalangi dan/atau tidak melaksanakan prinsip syariah dalam menjalankan usaha atau tugasnya atau tidak memenuhi kewajibannya sebagaimana ditentukan dalam undang-undang ini.

Sanksi administratif tersebut berdasarkan Pasal 58 ayat 1 Undang-Undang Nomor 21 Tahun 2008 tentang Perbankan Syariah dapat berupa:

a. Denda uang;

b. Teguran tertulis;

c. Penurunan tingkat kesehatan bank syariah dan UUS;

d. Pelarangan untuk turut serta dalam kegiatan kliring;

e. Pembekuan kegiatan usaha tertentu, baik untuk kantor cabang tertentu maupun untuk bank syariah dan UUS secara keseluruhan;

f. Pemberhentian pengurus bank syariah dan bank umum konvensional yang memiliki UUS, dan selanjutnya menunjuk dan mengangkat pengganti sementara sampai Rapat Umum Pemegang Saham mengangkat pengganti yang tetap dengan persetujuan Bank Indonesia;

g. Pencantuman anggota pengurus, pegawai, dan pemegang saham bank syariah dan bank umum konvensional yang memiliki UUS dalam daftar orang tercela di bidang perbankan; dan/atau

h. Pencabutan izin usaha.

Di samping itu, Peraturan Otoritas Jasa Keuangan (POJK) Nomor 24/POJK.03/2015 tentang Produk Dan Aktivitas Bank Syariah Dan Unit Usaha Syariah, Pasal 14 Ayat 1 huruf a, bahwasanya Otoritas Jasa Keuangan berwenang memerintahkan bank untuk menghentikan produk dan/atau aktivitas dalam hal: "Tidak sesuai dengan prinsip syariah; dan/atau Tidak sesuai dengan perundang-undangan". Dalam huruf b dijelaskan bahwa penghentian aktivitas suatu produk berdasarkan evaluasi Otoritas Jasa Keuangan, apabila penerbitan produk dan/atau pelaksanaan aktivitas dinilai atau berpotensi: "meningkatkan risiko hukum atau reputasi bank secara signifikan karena adanya pengaduan atau tuntutan dari nasabah".

Pasal-pasal di atas menjelaskan bahwa Unit Mikro Syariah di PT. Bank Rakyat Indonesia Syariah Cabang Lhokseumawe, dalam melakukan pembiayaan secara akad murabahah bil wakalah tidak memenuhi prinsip syariah, sehingga Unit Mikro Syariah 
di PT. Bank Rakyat Indonesia Syariah Cabang Lhokseumawe dapat dikenakan sanksi administratif dengan tegas disebabkan tidak menjalankan sesuai dengan aturan yang telah ditetapkan oleh Undang-Undang Nomor 21 Tahun 2008 tentang Perbankan Syariah maupun Peraturan Otoritas Jasa Keuangan (POJK) Nomor 24/POJK.03/2015 tentang Produk Dan Aktivitas Bank Syariah Dan Unit Usaha Syariah.

Permasalahan-permasalahan yang telah dijelaskan di atas, bahwasanya pelaksanaan akad pembiayaan murabahah bil wakalah yang dijalankan oleh Unit Mikro Syariah di PT. Bank Rakyat Indonesia Syariah Cabang Lhokseumawe tidak terwujud suatu kemaslahatan. Dikarenakan dalam pelaksanaan akad pembiayaan murabahah bil wakalah tersebut belum memenuhi prinsip jual beli murabahah sehingga menimbulkan unsur yang diharamkan dalam Islam yaitu riba.

Melihat dari segi keberadaannya, pelaksanaan akad pembiayaan murabahah bil wakalah yang dilakukan oleh Unit Mikro Syariah di PT. Bank Rakyat Indonesia Syariah Cabang Lhokseumawe termasuk ke dalam maslahah mulghah, yaitu kemaslahatan yang ditolak karena bertentangan dengan syara'. Imam Al-Ghazali memandang bahwa kemaslahatan harus sejalan dengan tujuan syara', sekalipun itu bertentangan dengan pola pikir manusia. Karena kemaslahatan yang dikehendaki manusia tidak selamanya didasarkan pada tujuan syara' yang sebenarnya, akan tetapi lebih sering didasarkan pada kehendak hawa nafsunya.

Allah SWT dengan tegas melarang mengikuti hawa nafsu seperti yang disebutkan dalam QS. Al-Qashshash Ayat 50 yang artinya:

Maka jika mereka tidak menjawab (tantanganmu) ketahuilah bahwa sesungguhnya mereka hanyalah mengikuti hawa nafsu mereka (belaka). Dan siapakah yang lebih sesat daripada orang yang mengikuti hawa nafsunya dengan tidak mendapat petunjuk dari Allah sedikitpun. Sesungguhnya Allah tidak memberi petunjuk kepada orang-orang yang zhalim.

Allah SWT juga berfirman dalam QS. Al-Maidah Ayat 77 yang artinya:

Katakanlah, "Hai Ahli Kitab! Janganlah kamu berlebih-lebihan (melampaui batas) dengan cara tidak benar dalam agamamu. Dan janganlah kamu mengikuti hawa nafsu orang-orang yang telah sesat dahulunya (sebelum kedatangan Muhammad) dan mereka telah menyesatkan kebanyakan (manusia), dan mereka tersesat dari jalan yang lurus.

Syaikhul Islam Rahimahullah berkata, barangsiapa mengikuti hawa nafsu manusia setelah mereka mengetahui agama Islam yang Allah amanahkan kepada Rasul-Nya untuk membawa agama itu dan juga setelah mengetahui petunjuk Allah yang telah dijelasakan kepada para hamba-Nya, berarti dia berada dalam kedudukan ini (yaitu sebagai pengikut hawa nafsu). Oleh karena itu para salaf menamakan ahli bid'ah dan orang-orang yang berpecah-belah, orang-orang yang menyelisihi Al-Qur'an dan Al-Hadits sebagai ahlul ahwa' (orang-orang yang mengikuti hawa nafsu). Karena 
mereka menerima apa yang mereka suka dan menolak apa yang mereka benci dengan dasar hawa nafsu (kesenangan semata), tanpa petunjuk dari Allah SWT. Dengan demikian, maka dalam menjalankan segala sesuatu adalah harus sesuai dengan ketentuan syara'. Menurut Imam Al-Ghazali juga yang menjadi tujuan Syara' adalah berupa memelihara agama, jiwa, akal budi, keturunan dan harta kekayaan. Selain itu menurut As-Syatibi, kemaslahatan tidak dibedakan antara kemasalahatan dunia maupun akhirat, karena keduanya tersebut apabila bertujuan untuk memelihara kelima tujuan syara' diatas maka dikatakan maslahah.

Dengan demikian, bahwasanya suatu kewajiban atau keharusan Unit Mikro Syariah di PT. Bank Rakyat Indonesia Syariah Cabang Lhokseumawe, menjalankan aktivitas bisnisnya khususnya dalam akad pembiayaan murabahah bil wakalah mewujudkan kemaslahatan dengan memelihara agama, jiwa, akal budi, keturunan dan harta kekayaan dengan menerapkan prinsip syariah. Prinsip syariah disini adalah sebagaimana yang telah dituangkan dalam DSN-MUI, Undang-Undang Perbankan Syariah, Peraturan Bank Indonesia maupun Peraturan Otoritas Jasa Keuangan. Karena akibat yang ditimbulkan dari pelakasanaan akad pembiayaan murabahah bil wakalah tersebut tidak hanya berdampak terhadap sanksi hukum positif saja, akan tetapi juga akan berdampak terhadap sanksi Hukum Islam.

\section{Penutup}

Pelaksanaan akad pembiayaan murabahah bil wakalah yang dilakukan oleh Unit Mikro Syariah di PT. Bank Rakyat Indonesia Syariah Cabang Lhokseumawe tidak sah dan batal demi hukum, karena dalam pelaksanaannya Unit Mikro Syariah di PT. Bank Rakyat Indonesia Syariah Cabang Lhokseumawe mengadakan akad murabahah sebelum barang dibeli oleh nasabah sebagai wakil dari bank dan barang secara prinsip belum menjadi milik bank. Kesalahan prosedur tersebut mengakibatkan tidak terpenuhinya prinsip jual beli murabahah berdasarkan syariah, dan pembiayaan yang dilaksanakan tersebut termasuk kategori pinjaman biasa (kredit) dengan tambahan keuntungan dan hal ini termasuk riba. Akibatnya, PT. Bank Rakyat Indonesia Syariah Cabang Lhokseumawe dapat dikenakan sanksi administratif berdasarkan UndangUndang Perbankan Syariah, Peraturan Bank Indonesia dan Peraturan Otoritas Jasa Keuangan.

\section{DAFTAR PUSTAKA}

Ali, Zainuddin, 2007, Hukum Perbankan Syariah, Sinar Grafika, Jakarta

Fauzi, Muhammad, "Analisis Faktor-Faktor Yang Mempengaruhi Keinginan Migrasi Nasabah Bank Umum Syariah di Kota Semarang”, IAIN Walisongo, Semarang : 2008 
Faisal, "Metode Anuitas Dan Proporsional Murabahah Sebagai Bentuk Transparansi Dan Publikasi Laporan Bank", Mimbar Hukum Volume 26, No. 3, Oktober 2014

Fatwa Dewan Syariah Nasional Nomor No. 04/DSN-MUI/IV/2000 tentang Murabahah

Kartodirodjo, Sartono dalam Cholil Nafis, 2011, Teori Hukum Ekonomi Syariah, UIPress, Jakarta

Kunaifi, Kuniafi, "Peran Dewan Syariah Nasional-Majelis Ulama Indonesia Dalam Perbankan Syariah", Makalah Program Pasca Sarjana Universitas Sunan Giri Surabaya, Surabaya : 2013

Muhammad, 2005, Manajemen Pembiayaan Bank Syariah, AMP YKPN, Yogyakarta Peraturan Bank Indonesia Nomor 11/33/PBI/2009 tentang Pelaksanaan Good Corporate Governance Bagi Bank Umum Syariah Dan Unit Usaha Syariah (Lembaran Negara No. 175 Tahun 2009)

Peraturan Otoritas Jasa Keuangan Nomor 24/POJK.03/2015 tentang Produk Dan Aktivitas Bank Syariah Dan Unit Usaha Syariah (Lembaran Negara No. 289 Tahun 2015)

Undang-Undang Nomor 21 Tahun 2008 tentang Perbankan Syariah (Lembaran Negara Republik Indonesia No. 94 Tahun 2008) 